\title{
IDENTIFYING THE FACTORS DRIVING MARKET SELECTION IN LATIN AMERICA
}

\author{
*Verónica BAEÑA \\ **Julio CERVINO \\ *European University of Madrid \\ **Carlos III University Of Madrid
}

\begin{abstract}
Despite of the fact that the body on international marketing focuses on emerging markets is growing, the attention paid to the Latin American context continues to be very limited. In an attempt to enhance the knowledge that managers and scholars have on franchising expansion, the present study examines how a number of market conditions may constrain diffusion of franchising into those nations. They are: i) geographical distance; ii) cultural distance; iii) uncertainty avoidance; iv) individualism; and vi) economic development. Also, we controlled for the host country's economic potential, political stability, unemployment rate, and corruption. This study uses a quantitative approach applied to a sample of 63 Spanish franchisors operating through 2,321 franchisee outlets across 20 Latin American countries in January 2010. They are: Argentina, Brazil, Chile, Colombia, Costa Rica, Cuba, Dominican Republic, Ecuador, El Salvador, Guatemala, Haiti, Honduras, Mexico, Nicaragua, Panama, Paraguay, Peru, Puerto Rico, Uruguay and Venezuela. Results conclude that cultural distance between the host and home country, as well as the level of host's country economic development and potential are able to constrain the spread of international franchising across Latin American nations. In sum, this work explores how market conditions may drive international diffusion of franchising into Latin American markets. The scant theoretical or empirical attention given to this topic has usually been examined from a U.S. base and focused on developed markets. To fill this gap, the present study analyzes the international spread of the Spanish franchise system (ranked fifth in worldwide terms) into Latin America as a market for franchising expansion. Thus, franchisors may use the results of this study as a benchmark study and a starting point for identifying the Latin American regions whose characteristics best meet their needs of expansion.
\end{abstract}

KEYWORDS: Franchising, Market Selection, Latin America, Country Choice

\section{INTRODUCTION}

The literature on franchising has fully covered issues such as why firms should organize as a franchise chain and engage franchisees (Lafontaine and Kaufmann, 1994; Alon, 2001; 2005), franchising efficiency (Lafontaine, 1992), and the relationship between franchisor and franchisee (Sanders, 2002). In contrast, although recently greater effort has been made to examine the scope of franchising from an international standpoint, international franchising has generally received limited academic attention (Quinn and Doherty, 2000; Baena, 2009; Alon, 2010; Baena, 2011). Moreover, the scant theoretical and empirical attention given to this topic has generally been examined from a U.S. and British base. Thus, there is a great need for a deeper explanatory models of international diffusion via franchising, one that can explore this issue by focusing on franchising systems other than those from the U. S. or British models.

The present study attempts to cover this gap by introducing a model that explores a set of host country factors in the rate of the Spanish franchise diffusion among Latin American nations. This because, although franchising in the U.S., Canada, and parts of Western Europe has reached domestic market saturation (Alon, 2010), Latin American markets remain relatively untapped. This is surprising given the substantive economic importance of the region with a population over 550 million, and a GDP of approximately US $\$ 4$ trillion. Additionally, most Latin American countries, including the largest ones (Argentina, Mexico, Brazil, Chile, Peru, Venezuela, and Colombia), show per capita GDP greater than that of China in 2009, as of 2010 Latin America included five nations classified as high-income countries: Chile, Mexico, Argentina, Uruguay and Panama. Nevertheless, research in international marketing in the Latin American context is very limited (Birnik and Browman, 2007; Fastoso and Whitelock, 2010). Specifically, we propose a set of variables as those affecting international expansion into Latin America via franchising. In order to advance our understanding, we focus on the Spanish franchise system, which since 2008 has been fifth worldwide both in terms of the number of franchisors $(1,019)$ 
and the quantity of franchisee outlets $(65,026)$ having presence in 112 foreign countries through 172 chains with a total of 10,186 outlets in early 2010. As a result, we think this work may be useful not only to academics wishing to enhance their knowledge about international franchising, but also to franchise chains willing to establish new outlets in Latin America. These will be our major contributions.

\section{THEORETICAL FRAMEWORK AND PROPOSITION DEVELOPMENT}

Transaction cost analysis (TCA) offers a rich framework for examining the efficiency of franchising. It posits that firms choose to internalize or externalize exchange relationship based primarily on cost incurred in the exchange process (Liang, Musteen and Datta, 2009). This framework asserts that franchising is a hybrid organization form, located somewhere between the extremes of vertical integration on the one hand, and completely independent operations on the other. For the franchisor, this agentprincipal relation will impact appreciably on the success or failure of foreign market entry by using a particular organizational form (Burton, Cross and Rhodes, 2000). Therefore, a framework based on TCA is developed to infer the variables constraining international franchising expansion into Latin American markets, based on a country level perspective.

\section{Geographical Distance}

Multinational companies tend to internationalize through country markets that are more easily understood by managers (Rahman, 2003). According to this point, Fladmoe-Lindquist (1996) posed the problem of geographical distance from the standpoint of efficiency by showing that under geographical distance monitoring activities are more difficult and expensive. Furthermore, geographical distance makes logistical support more difficult especially when inputs have to be imported from the home country. The above-mentioned costs are substantially higher in foreign markets that span continents and time zones, despite recent improvements in transportation and communication technology. Under these conditions, franchising may help to prevent moral hazardous and adverse selection without requiring site visits with their accompanying travel difficulties, and the need for regional monitoring facilities in global markets (Sashi and Karuppur, 2002). Firms can then reduce monitoring cost by involving local partners as franchisees in distant markets. Nevertheless we can also argue the opposite effect. This is because as spatial distance increases, however, so too will transaction costs. Search costs may increase because franchisors need to expend greater resources to identify and contract with acceptable candidates for franchisees. Moreover, servicing costs may increase if elements of the franchise package need to be transported from home country to host country (Burton, Cross and Rhodes, 2000). Following the previous discussion, we propose the following:

Hypothesis $1_{\mathrm{a}}$ : The expansion of franchising across Latin American nations will be positively associated with high geographical distance between the home and the host country.

Hypothesis $1_{\mathrm{b}}$ : The expansion of franchising across Latin American nations will be negatively associated with high geographical distance between the home and the host country.

\section{Cultural Distance}

Traditionally, cultural distance has been fully considered by literature given that it is well known that differences among markets in cultural values hinder the transfer of management skills as well as company's products and services, which involve higher transactions within an organization (Anderson and Gatignon, 1986). As reported in Fladmoe-Lindquist and Jacque (1995), franchising is more likely in countries that are culturally distant from the home country. Consequently, when cultural distances are small, firms may adopt the same mode of operation as in domestic markets, and only firms that franchise in the domestic market may prefer to do the same in global. In contrast, when cultural distances are significant, however, even firms that favor high ownership arrangements in domestic markets may prefer adopting low ownership agreements in global markets (Alon and McKee, 1999). Furthermore, companies operating globally will have to understand the complexity of different cultures in order to set standards for control and evaluation. Otherwise, firms would transfer the responsibility for such decisions to local partners, who will be able to set standard bases on local practices and regulations to evaluate the performance of the business and its employees (Sashi and Karuppur, 2002).

On the basis of the preceding arguments, we argue that franchising may be chosen when cultural distance is significant as it allows franchisors to transfer responsibility for managing local operations to 
franchisees. However, we can also postulate the opposite effect because as cultural distance increase, transaction costs may increase if elements of the franchise package need tailoring to accommodate local market conditions (Eroglu, 1992). Furthermore, monitoring cost are likely to increase if differences in business ethics and practices between the franchisor and franchisee become more pronounced, rendering it less easy (or more costly) to ensure the satisfactory performance of the latter (Burton, Cross and Rhodes, 2000). Therefore, we propose the following:

Hypothesis $2_{\mathrm{a}}$ : The expansion of franchising across Latin American nations will be positively associated with higher cultural distance between the home and the host country.

Hypothesis $2_{\mathrm{b}}$ : The expansion of franchising across Latin American nations will be negatively associated with higher cultural distance between the home and the host country.

\section{Uncertainty Avoidance and Individualism}

Hofstede's research (1991) has revealed that cultures differ on four different dimensions: 1) tolerance for ambiguity or uncertainty avoidance; 2) power distance; 3) individualism/collectivism; and 4) masculinity. All of them were calculated for different countries and have been highly cited in the literature (Mitra and Golder, 2002). Related to the previous descriptions, entrepreneurs from cultures having high uncertainty avoidance (low tolerance for ambiguity) might be more likely to adopt franchising because of their lack of willingness to take calculated jeopardy. Specifically, franchising has been traditionally considered as a method of economic development that reduces entrepreneurial risk by transferring a proven retail concept as well as management and marketing expertise (Michael, 2003). Nevertheless, franchising does not eliminate all business risks. In addition, people that scored high in uncertainty avoidance would prefer rules and structured circumstances rather than emotions and innovation. Consequently, it could be argued that local agents showing high uncertainty avoidance would prefer being employees rather than franchisees.

Moreover, cultures that favor individual achievement and competition should tend to reward entrepreneurship, given that cultures with individualistic values are more likely to develop organizational strategies based on entrepreneurship, such as franchising (Hoffman and Preble, 2001). However, we could also predict the opposite effect as individualist people may prefer choosing their own decision (entrepreneurship) rather than been franchisees subjected to franchisor's rules. Hence, based on the previous discussion we make the following propositions:

Hypothesis $3_{\mathrm{a}}$ : The expansion of franchising across Latin American nations will be positively associated with national cultures possessing high uncertainty avoidance.

Hypothesis $3_{\mathrm{b}}$ : The expansion of franchising across Latin American nations will be positively associated with national cultures possessing low individualism.

Hypothesis $4_{\mathrm{a}}$ : The expansion of franchising across Latin American nations will be positively associated with national cultures possessing high individualism.

Hypothesis $4_{b}$ : The expansion of franchising across Latin American nations will be positively associated with national cultures possessing low individualism.

\section{Economic Development}

As economies become more affluent, there is a greater shift to services which, as shown by Hoffman and Preble (2001) provide more opportunities for firms to expand. Moreover, countries with high economic development usually imply less exposure to political and economic risk (Herrmann and Datta, 2002) and therefore, the number of franchisors willing to enter into increases (Alon, 2010; Baena, 2011). Nevertheless, we could also predict the opposite effect. This is because expanding across foreign countries via franchising entails several advantages for the franchisor as fewer financial resources required and reduced susceptibility to political economic and other risks (Quinn and Doherty, 2000; Welsh, Alon and Falbe, 2006). However, profits are shared with the local agent - franchisee -. As a result, companies entering into markets showing high economic potential and business growth may be willing to expand their business abroad by using their own resources (joint venture or $100 \%$ direct investment) and therefore, getting all business benefits. Based on the previous arguments we make the following propositions:

Hypothesis $4_{\mathrm{a}}$ : The expansion of franchising across Latin American nations will be positively associated with countries possessing high economic development. 
Hypothesis $4_{b}$ : The expansion of franchising across Latin American nations will be positively associated with countries possessing low economic development.

\section{DATA GATHERING PROCESS AND METHODOLOGY}

Data on international franchising activity was obtained from the Spanish franchise system, which as of 2008 has ranked fifth worldwide in terms of both the number of franchisors and the quantity of franchisee outlets. To test the hypotheses, we contacted the Spanish Franchise Association and the main Spanish franchising Consultant Group: Tormo \& Asociados. We finally obtained data on 2,321 outlets established by 63 Spanish franchise chains across 20 Latin American nations in January 2010. Specifically, the list of Latin American countries comprises the following nations: Antigua and Barbuda, Argentina, Bahamas, Barbados, Belice, Bolivia, Brazil, Chile, Colombia, Costa Rica, Cuba, Dominican Republic, Ecuador, El Salvador, Grenada, Guatemala, Guyana, Haiti, Honduras, Jamaica, Mexico, Nicaragua, Panama, Paraguay, Peru, Puerto Rico, Saint Lucia, Saint Kitts and Nevis, Saint Vincent and the Grenadines, Suriname,Trinidad and Tobago, Uruguay and Venezuela. In early 2010, Spanish franchisors were doing business in 20 of them: Argentina, Brazil, Chile, Colombia, Costa Rica, Cuba, Dominican Republic, Ecuador, El Salvador, Guatemala, Haiti, Honduras, Mexico, Nicaragua, Panama, Paraguay, Peru, Puerto Rico, Uruguay and Venezuela.

\section{Dependent Variables}

The international diffusion of franchising was assessed by considering the number of Spanish franchisee outlets (OUTLETS) located in Latin American countries. This variable spans from 1 franchisee outlet in a specific country (Haiti) to 498 (Mexico). As stated before, a total of 2,321 outlets were computed. However, this measure does not always reveal the degree of international expansion. Specifically, it is possible that some franchisors have different franchisee outlets located abroad but all of them established in the same foreign country. In this case, the international expansion of such a company would be very limited. In order to deal with this problem, we have created a second dependent variable to garner more information regarding the likelihood of choosing some markets for international expansion via franchising. This new variable is defined as the number of Spanish franchisors companies (FRANCHISOR) doing business in each Latin American country. This variable spans from 1 (Haiti) to 63 (Mexico). Also, the international diffusion of foreign franchisors across Latin America was assessed by considering the franchising penetration among those markets (FRPENETR); that is, the number of Spanish franchisors in each Latin American nation divided by the number of franchisee outlets established by Spanish franchise chains in that country. It ranks from 1 (Haiti and Paraguay) to 29 (Argentina).

\section{Independent and Control Variables}

The geographical distance (GEODIST) was determined by computing the kilometer distance between Spain (the home country of franchisors considered in this manuscript) and the Latin American country (host country). In some cases, we were not able to know the exact physical location of the franchisee outlets considered in this work. Thus, geographical distance was drawn from the kilometer distance between the capital of the franchisor's home country (Madrid, by default), and the capital of the nation where the franchisee outlet is located. Cultural distance (CULTDIST) was assessed by using Hofstede's (2001) work, which updates Hofstede's (1980) study. This manuscript uses Kogut and Singh's (1988) index on each of the Hofstede dimensions, an approach which has been used very often both in the traditional literature as well as in recent research (see. e.g., Sakarya, Eckman and Hyllegard, 2007; Slangen and Van Tulder, 2009, Yamin and Golesorkhi, 2010). In this data set the cultural distance index varies from 0 (for Spain, by default) to 6.69 (Venezuela). Data on uncertainty avoidance (UNCERAVOID) and individualism (INDIVIDUA) was also obtained from Hofstede's (2001).

The level of economic development (ECODEV) was measured in terms of GDP per capita, because of its association with the population's wealth, the extent of the middle class, and the level of development of the industrial and service sectors (Alon and McKee, 1999; Alon, 2010). Thus, data published by the International Monetary Fund in 2009 was considered. Political stability (POLITSTAB) was assessed by using data published in 2009 by the International Monetary Fund (IMF). The 2009 World Bank Report was used to measure the unemployment rates of each nation (UNEMPLOY). Regarding the host country's economic potential, it was measured by using data published by the International Monetary Fund in late 2009 about country population (POPULATION), as suggested in recent litera- 
ture (see, e.g., Rahman, 2003; Sakarya, Eckman and Hyllegard, 2007). Finally, the Transparency International Index in 2009 was considered to measure country corruption (TRANSPAREN).

\section{RESULTS}

The descriptive statistics are reported in Table 1. Additionally, Table 2 show the correlation matrix among variables and the results obtained from the regression analyses, respectively. We should point out that those variables that weren't normally distributed entered the model in logarithmic form. Also, Table 2 illustrates the collinearity statistics for all the variables used in the empirical analysis in each model. As shown, none is significant, suggesting that collinearity was not a problem in our regression models. For additional confirmation of these results, we calculated the determinant of the correlation matrix of each of the six models, finding a value of 1 , and were thus able to rule out problems of multicollinearity. Models 1a and 2a consider the number of Spanish franchisors (FRANCHISOR) in Latin American markets as a dependent variable. In contrast, in Models $2 \mathrm{a}$ and $2 \mathrm{~b}$ the dependent variable is measured by using the number of Spanish franchisee outlets (OUTLETS). Finally, in Models 3a and $3 \mathrm{~b}$ the dependent variable is assessed by considering the Spanish franchise penetration among Latin American markets (FRPENETR). Furthermore, Models 1a, 2a, and 3a test whether cultural distance (CULTDIST) is one of the factors capable of constraining the spread of international franchising across Latin America. However, this study argues that a predicted effect of cultural distance may be only applicable to two of the five Hofstede cultural dimensions: uncertainty avoidance and individualism. As a result, in order to avoid heterocedasticity, Models $1 b, 2 b$, and $3 b$ examine the effect of these dimensions (RISKAVER and INDIVIDUA) by omitting the cultural distance variable.

Table 1: descriptive statistics

\begin{tabular}{|l|r|r|r|r|}
\hline & MAXIMUN & MINIMUN & \multicolumn{1}{|c|}{ MEAN } & STANDARD DEVIATION \\
\hline FRANCHISOR & 63.000 & 1.000 & 5.690 & 13.416 \\
OUTLETS & 498.000 & 1.000 & 8.251 & 170.024 \\
FRPENETR & 29.000 & 1.000 & 2.331 & 8.392 \\
GEODIST & $10,039.000$ & $6,383.000$ & $8,212.592$ & $1,018.069$ \\
CULTDIST & 6.880 & 0.720 & 2.052 & 2.175 \\
RISKAVER & 101.000 & 11.000 & 54.498 & 24.876 \\
INDIVIDUA & 46.000 & 6.000 & 14.110 & 12.405 \\
POLITSTAB & 42.600 & 1.500 & 4.471 & 9.228 \\
TRANSPAREN & 7.800 & 1.900 & 3.422 & 1.701 \\
ECODEV & 22.120 & 2.650 & 7.930 & 4.742 \\
UNEMPLOY & 27.800 & 1.340 & 5.194 & 6.062 \\
POPULATION & $193,024,000.000$ & $3,322,000.000$ & $8,768,747.441$ & $47,746,371.689$ \\
\hline
\end{tabular}

Focusing on Models 1a and 1b, results illustrate that the Latin American countries that attract more Spanish franchise chains (FRANCHISOR) are characterized by high levels of economic development (ECODEV) and cultural distance (CULTDIST). Thus, hypotheses H2a and H4a were supported at the 0.05 level. As mentioned, international expansion of franchising across Latin American markets has been analyzed not only according to the number of franchisors (FRANCHISOR) but also by considering the number of franchisee outlets located in those countries (OUTLETS). Results are shown in Models $2 \mathrm{a}$ and $2 \mathrm{~b}$. The difference between these models is that the former uses cultural distance (CULTDIST) as an independent variable whereas this variable is substituted by individualism (INDIVIDUA) and uncertainty avoidance (RISKAVER) in Model 2b. As expected, the level of economic development (ECODEV) was significant and positively associated with the dependent variable in both models. Hence, H4a was supported at the 0.05 level. Furthermore, concerning the third dependent variable considered in this manuscript (FRPENETR), Models 3a and 3b show that Spanish franchise chains prefer to expand across Latin American nations characterized by largest levels of economic development (ECODEV) and therefore, hypothesis H4a was supported at the 0.05 level. Finally, the effect of market potential (POPULATION) on the franchise diffusion across Latin American countries was included as a control variable. Results show a positive and significant association between that variable and the number of Spanish franchise chains (FRANCHISOR), franchisee outlets (OUTLETS), as well the number of franchisors in comparison with the number of franchisee outlets (FRPENTR) in Latin America at the 0.05 level. 
Table 2: regression analyses

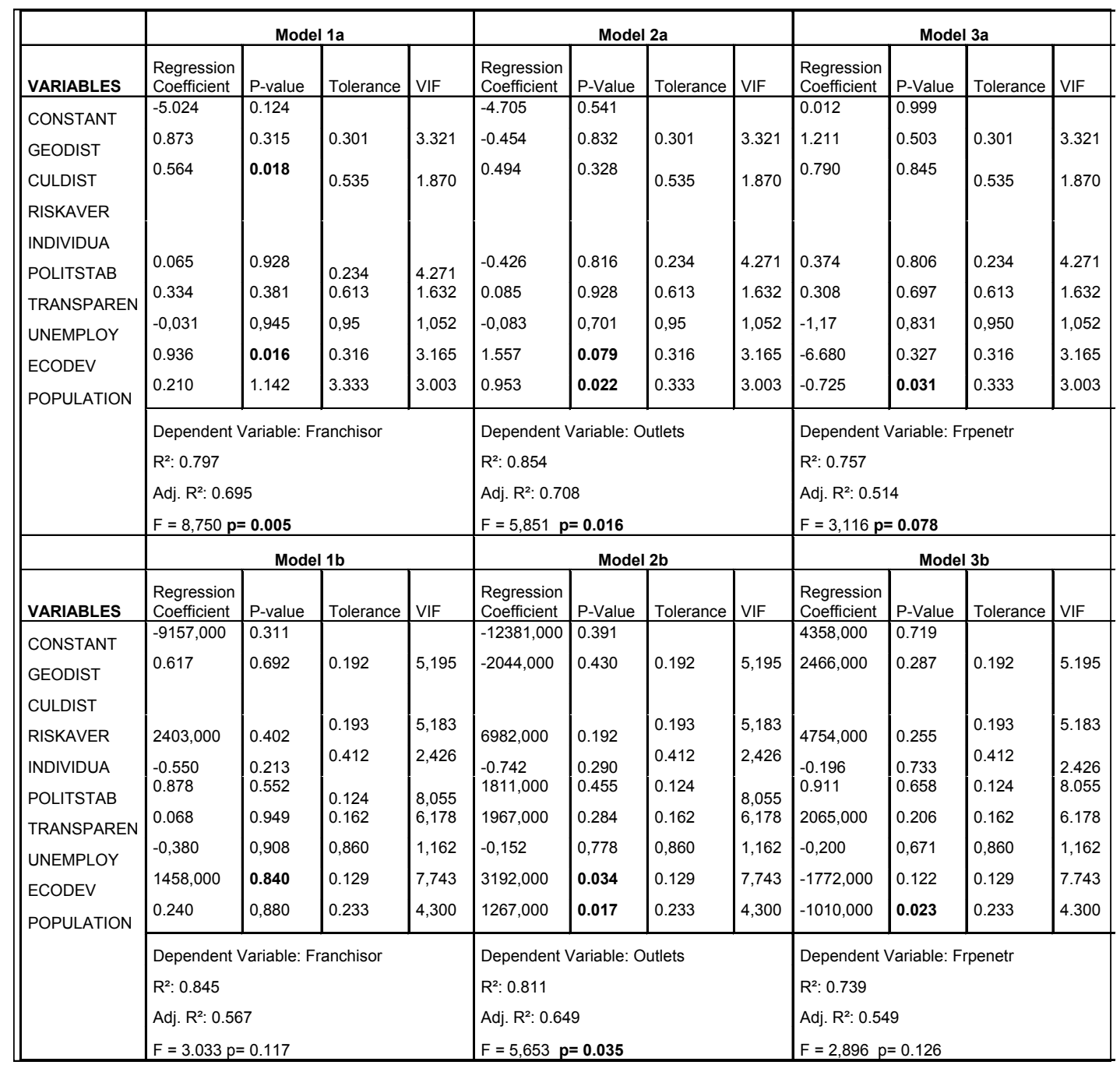

\section{DISCUSSION AND CONCLUSIONS}

Our results offer firm conclusions regarding the factors driving global franchising expansion. The factors we suggested determine which Latin American countries are more favored when entering markets through this type of business organization. Nonetheless, the results at the variable level are mixed. On the one hand, the positive coefficient of GDP per capita found in all the models emphasizes the idea that as the level of economic development increases, so too will market opportunities. Therefore, the number of foreign franchisor willing to enter into that nation increases. Another contribution of this paper is that it reveals that when cultural distances increases, firms operating globally will have to understand the complexity of different cultures in order to set standards for evaluation and monitoring (Alon and McKee, 1999; Sashi and Karuppur, 2002). Therefore, according to the positive correlation of the aggregate cultural distance dimension with franchise diffusion, foreign investors prefer adopting low ownership agreements, like franchising, to transfer the responsibility for such decisions to local partners, who will be able to set standard bases on local practices and regulations to evaluate the performance of employees in Latin America. This paper also shows that Hofstede's conceptualization of culture may not be valid for examining market conditions constraining international franchise diffusion across Latin American markets. Therefore, in spite of Hofstede's (1980) study being cited on more than 1,000 occasions, and being widely used in the literature (see, e.g., Baena, 2009; Slangen and Van Tulder, 2009, Yamin and Golesorkhi, 2010; Baena, 2011, among others), no significant association was found between this variable and five of the six models considered in this manuscript.

Regarding the two other cultural hypotheses, results illustrate the expansion of franchising across Latin American nations is positively associated with cultures possessing low individualism and high uncertainty avoidance. This indicates that local agents view franchising as a method for minimizing 
business risk (transferring a proven successful business concept and the most efficient way to manage the firm). Thus, agents with high uncertainty avoidance may opt for buying a franchise instead of opening a new business from scratch. Nevertheless, the fact that franchisees have to adopt the franchisor's rules and decisions can help explain why franchising shows higher presence in countries characterized by low individualism. Nonetheless, we need to treat these claims with some caution, however, since they did not prove to be statistically significant. Likewise, none significant evidence was found among a host country's political stability, transparency, unemployment and international expansion via franchising.

In sum, the present study provides insights which prove that international franchising expansion into Latin American countries depends on various country variables that franchisors may evaluate before selecting suitable markets to enter. 


\section{REFERENCES}

Alon, I. (2001), The Use of Franchising by U.S. Based Retailers. Journal of Small Business Management, 32, pp.111-122.

Alon, I. (2005), Service Franchising: A Global Perspective, Springer, New York, USA.

Alon, I. (2010), Franchising Globally, New York: Palgrave MacMillan, USA.

Alon, I. and McKee, D. (1999). Towards a Macro Environmental Model of International Franchising. Multinational Business Review, 7, pp.76-82.

Anderson, E. and Gatignon, H. (1986). Modes of Foreign Entry: A Transaction Cost Analysis and Propositions, Journal of International Business Studies, 17, pp.1-26.

Baena, V. (2011). The Effect of Corruption on Global Franchising in Emerging Markets, International Journal of Business and Emerging Market, 3, pp. 57-74

Baena, V. (2009). Modeling Global Franchising in Emerging Markets. An Entry Mode Analysis, Journal of East West Business, 15, pp. 164-188.

Birnik, A. and Bowman, C. (2007). Marketing Mix Standardization in Multinational Corporations, A Review Of The Evidence. Journal of Management Review, 9, pp.303-324

Burton, F., Cross, A. R. and Rhodes, M. (2000), Foreign Market Servicing Strategies of UK Franchisors: An Empirical Enquiry from a Transaction Cost Perspective, Management International Review, 40, pp.373 -400 .

Eroglu, S. (1992), The Internationalization Process of Franchise Systems: A Conceptual Model, International Marketing Review, 9, pp.19-30.

Fastoso, F. and Whitelock, J. (2010). Regionalization vs. Globalization in Advertising Research. Insights from Five Decades of Academic Study, Journal of International Management, 16, pp.32-42

Fladmoe-Lindquist, K. (1996). International Franchising: Capabilities and Development, Journal of Business Venturing, 11, 419-438.

Fladmoe-Lindquist, K. and Jacque, L. (1995), Control Modes in International Service Operations, The Propensity To Franchise, Management Science, 9, pp.1238-49.

Herr, P.M., Farquhar, P.H. and Fazio, R.H. (1996), Impact On Dominance and Relatedness on Brand Extensions, Journal of Consumer Psychology, 5, 135-159.

Herrmann, P., and Datta, D. K. (2002), CEO Successor Characteristics and the Choice If Foreign Market Entry Mode: An Empirical Study, Journal of International Business Studies, 33, 551-570.

Hoffman, R. and Preble, J. (2001), Global Diffusion of Franchising. A Country Level Examination, Multinational Business Review, 9, pp.66-75.

Hofstede, G. (1980), Culture's Consequences: International Differences in Work-Related Values, Sage Publications, Beverly Hills, C. A., USA.

Hofstede, G. (1991) Culture and Organizations, McGraw Hill, New York, USA.

Hofstede, G. (2001), Culture's Consequences: Comparing Values, Behaviors, Institutions, and Organizations across Nations., Sage Publications, Thousand Oaks C.A., USA.

Kogut, B. and Singh, H. (1988), The effect of national culture on the choice of entry mode, Journal of International Business Studies, 19, pp.411-432.

Lafontaine, F. (1992). Agency Theory and Franchising: Some Empirical Results, Rand Journal of Economics, 23, pp.263-283.

Liang, X., Musteen, M. and Datta, D. K. (2009). Strategic Orientation and the Choice of Foreign Market Entry Mode. Management International Review. 49, pp.269-290

Lafontaine, F. and Kaufmann, P. (1994), The Evolution of Ownership Patterns in Franchise Systems. Journal of Retailing, 70, pp.97-113.

Michael, S. C. (2003), Determinants of the Rate of Franchising among Nations, Management International Review, 43, pp.267-291. 
Mitra, D. and Golder, P. N. (2002), Whose Culture Matters: Near-Markets Knowledge and its Impact on Foreign Market Entry Timing, Journal of Marketing Research, 39, pp.350-365.

Quinn, B. and Doherty, A. M. (2000), Power and Control in International Retail Franchising. Evidence from Theory and Practice, International Marketing Review, 17, pp.354-371.

Rahman, S. H. (2003), Modeling International Market Selection Process: A Qualitative Study of Successful Australian International Businesses, Qualitative Market Research, 6, pp.119-132

Sakarya, S., Eckman, M. and Hyllegard, K. (2007), Market Selection for International Expansion. Assessing Opportunities in Emerging Markets, International Marketing Review, 24, pp.108-138

Sanders, L. (2002), Franchisee-Franchisor Relationships In the Future, Franchising World, 34(6, 23 24.

Sashi, C. M., and Karuppur, D. P. (2002), Franchising in Global Markets, Towards a Conceptual Framework, International Business Review, 19, pp.499-524.

Slangen, A. H. and Van Tulder, R. J. (2009), Cultural Distance, Political Risk, or Governance Quality Towards a More Accurate Conceptualization and Measurement of External Uncertainty in Foreign Entry Mode Research, International Business Review, 18, pp.276-291

Welsh, D., Alon, I. and Falbe, C. (2006), An Examination of International Retail Franchising in Emerging Markets, Journal of Small Business Management, 44, pp.130-150.

Yamin, M. and Golesorkhi, S. (2010), Cultural Distance and the Pattern of Equity Ownership Structure in International Joint Ventures, International Business Review, 19, pp.457-467 